\title{
Werbalne sposoby komunikowania „dociekliwości” przez felietonistów (Piotra Zarembę, Magdalenę Środę i Szymona Hołownię). Wyniki badań empirycznych ${ }^{1}$
}

\section{Wprowadzenie}

Choć wskazać można wiele badań dotyczących wizerunku i jego zmiennych $^{2}$, to już trudniej o analizy wizerunków tylko felietonistów ${ }^{3}$. Zazwyczaj badacze skupiają się na wybranych aspektach stylu czy języka określonego autora ${ }^{4}$,

\footnotetext{
* Mgr, e-mail: anna.baranska@uni.lodz.pl; Uniwersytet Łódzki, Katedra Dziennikarstwa i Komunikacji Społecznej, Zakład Teorii i Praktyki Komunikacji.

${ }^{1}$ Badania przytaczane w niniejszym artykule powstały w ramach projektu „Komunikowanie wizerunku na poziomie wypowiedzi werbalnej”, kod projektu: B15113000001067.02., finansowanego z dotacji celowej Wydziału Filologicznego Uniwersytetu Łódzkiego na prowadzenie badań naukowych przez młodych naukowców i uczestników studiów doktoranckich.

${ }^{2}$ Zob. np. wrocławską serię wydawniczą „Projektowanie komunikacji” (Libron), gdzie od kilku lat ukazują się m.in. kolejne tomy: Badanie i projektowanie komunikacji, Komunikacja w rozmowie oraz ostatnio Teoria komunikacji i mediów (wcześniej wydawnictwo Atut).

${ }^{3}$ Poniekąd tylko wizerunku felietonisty(-stki) dotyczą np.: O. Dąbrowska-Cendrowska, Krystyna Kofta jako reprezentantka felietonistów ,Twojego Stylu” w latach 1990-2009, [w:] Mistrzowie literatury czy dziennikarstwa?, red. K. Wolny-Zmorzyński, W. Furman, J. Snopek, Poltex, Warszawa 2011, s. 61-73; A. Mielżyńska, Roman Kurkiewicz jako felietonista, „Acta Universitatis Lodziensis. Folia Litteraria Polonica” 2011, nr 1 (14), s. 35-42. Bezpośrednio o image'u autora felietonu traktują następujące opracowania: A. Barańska-Szmitko, Wpływ użytej wwypowiedzi leksyki potocznej na wizerunek felietonisty, „Acta Universitatis Lodziensis. Folia Litteraria Polonica” 2016, nr 2(32): Stylistyka mediów, red. R. Siekiera, M. Worsowicz, s. 107-117; A. Barańska-Szmitko, Wizerunek Szymona Hołowni komunikowany w jego felietonach, [w:] Badanie i projektowanie komunikacji 3, red. M. Wszołek, Libron, Wrocław 2014, s. 173-197; A. Barańska-Szmitko, Wizerunek Krzysztofa Vargi komunikowany stowem. Reprezentacja językowa cech przypisywanych autorowi tekstu, [w:] Badanie i projektowanie komunikacji 2, red. M. Grech, A. Siemes, Wydawnictwo Libron, Wrocław 2013, s. 155-177.

${ }^{4}$ Wśród tego typu opracowań wymienić można m.in. tekst o „idiolektostylu” Krzysztofa Skiby w: A. Kudra, Idiolektostylem w mur, czyli o idiolekcie, idiostylu i krytycznej analizie dyskursu - na przyktadzie felietonów Krzysztofa Skiby w tygodniku ,Wprost”, „Acta Universitatis Lodziensis. Folia Litteraria Polonica" 2011, t. 1 (14), s. 27-34; albo charakterystykę stylu Jarosława
} 
stąd też wiele opracowań charakteryzujących konkretne cechy: komizm ${ }^{5}$, sposoby oceniania ${ }^{6}$, metaforykę ${ }^{7}$, funkcje prowokacji ${ }^{8}$, innowacje frazeologiczne ${ }^{9} \mathrm{w}$ felietonowych wypowiedziach.

Celem artykułu jest przedstawienie wstępnych wyników badań dotyczących sposobów komunikowania przez autora wypowiedzi werbalnej cechy, którą określamy jako dociekliwość. Prezentowane rezultaty uzyskano w ramach badania empirycznego, w którym respondenci po przeczytaniu tekstu felietonu Piotra Zaremby, Magdaleny Środy lub Szymona Hołowni przypisywali poszczególnym autorom charakterystyczne - w opinii ankietowanych - cechy, wśród których pojawił się także epitet ,dociekliwy”. Następnie wynotowali te fragmenty tekstu, które ich zdaniem odpowiadają za komunikowanie wskazanych cech, dzięki czemu na etapie analizy badawczej możliwe stało się wyłonienie i stypologizowanie sposobów komunikowania przymiotów twórców tekstów wypisywanych przez respondnetów na karcie odpowiedzi. W niniejszym artykule podejmuje się więc próbę empirycznej odpowiedzi na pytanie: jakimi sposobami felietonista komunikować może bycie „dociekliwym”.

Krawczyka, Jerzego Trammera i Michała Ogórka w: E. Sławkowa, Style współczesnego felietonu (Z zagadnień stylistyki gatunku), [w:] Gatunki mowy i ich ewolucja, t. 1: Mowy piękno wielorakie, red. D. Ostaszewska, WUŚ, Katowice 2000, s. 305-315; M. Wojtak, O doskonałości wypowiedzi publicystycznej na przykładzie felietonów J. Szczepkowskiej, [w:] O doskonałości, cz. 1, red. A. Maliszewska, Archidiecezjalne Wydaw. Łódzkie, Łódź 2002, s. 377-392. Analizę języka „pop-teologicznego" znaleźć można w: A. Kowal, Czy niebo to wieczny orgazm? Prowokacja jako swoistość języka religijnego Szymona Hołowni, „Kwartalnik Językoznawczy”2012, nr 4, s. 18-32. Dyskursowi danego publicysty poświęcony jest np.artykuł: Cz.K. Marczyk, Językowa przestrzeń felietonów literackich Czesława Miłosza, „Annales Academiae Paedagogicae Cracoviensis” 2005, Folia 26, Studia Historicolitteraria V, s. 185-193.

${ }^{5}$ M. Gaze Komizm językowy felietonach Tomasza Olbratowskiego, czyli o tekstach nie dla wszystkich, „Acta Universitatis Lodziensis. Kształcenie Polonistyczne Cudzoziemców” 2013, nr 20, s. 239-248; J. Mazur, W. Kozieja, Elementy humoru i karnawalizacji w felietonach mówionych Tomasza Olbratowskiego, [w:] Humor i karnawalizacja we wspótczesnej komunikacji językowej, red. J. Mazur, M. Rumińska, Wydawnictwo UMCS, Lublin 2007, s. 61-67.

${ }^{6}$ R. Pawelec, Sposoby oceniania w pismach publicystycznych Norwida oraz w publicystyce „Czasu” i ,Wiadomości Polskich”, [w:] Język Cypriana Norwida. Materiaty zorganizowane przez Pracownię Stownika Języka Norwida w dniach 4-6 listopada 1985 roku, red. K. Kopczyński, J. Puzynina, Wydawnictwo Uniwersytetu Warszawskiego, Warszawa 1990, s. 71-86.

${ }^{7}$ K. Paroń, Rzeczywistość to metafora - próba kognitywnej analizy metafor w felietonach Jerzego Urbana, „Acta Universitatis Lodziensis. Folia Litteraria Polonica” 2011, nr 1 (14), s. 43-53.

${ }^{8}$ J. Szydłowska, Besserwisser za katedra, czyli o funkcjach prowokacji w poetyce felietonu, „Napis” 2004, Seria X, s. 271-279.

${ }^{9}$ M. Olkowska, Frazeologiczne innowacje wymieniajace $w$ felietonistyce Agaty Passent, „Kwartalnik Językoznawczy” 2013, nr 1, s. 49-65. 


\section{Perspektywa badawcza}

W prowadzonych badaniach przyjęto perspektywę racjonalnego konstruktywizmu ${ }^{10}$, w którym istotny jest podział na wypowiedź i komunikat oraz na mówienie i komunikowanie. Wypowiedzi rozumiane są jako „materialne dane [...], które [...] dają sposobność do wytwarzania komunikatów"11. Komunikaty zaś powstają na podstawie wypowiedzi jako ,(re)konstruktywne rezultaty jakkolwiek rozumianych procesów percepcji indywidualnych interpretatorów"12 - w procesie odbioru i interpretacji. Natomiast,,o ile zatem mówienie sprowadza się do tego, co się mówi, o tyle komunikowanie odnosi się do tego, jak się to mówi i co się poprzez to, co i w jaki sposób się mówi, jeszcze komunikuje"13. Dla przykładu: można ,powiedzieć”, iż jest się ekspertem literatury i szczególnie ceni się renesans portugalski oraz jego czołową twórczynię Wisławę Szymborską za nowatorskie rozwiązania narracyjne, wprowadzone w Hamlecie. Wówczas powiedziało się nie więcej niż powyższe słowa, ale zakomunikowało się głęboką ignorancję w dziedzinie literatury. W omawianych niżej wynikach bierze się pod uwagę efekt komunikacyjny słów felietonistów (uznanie ich za „dociekliwych” - komunikat) oraz ukształtowanie wypowiedzi za ten efekt odpowiedzialne (sposoby komunikowania omawianej cechy).

Przebieg badania empirycznego, jak i sama analiza uwzględniały, że,,interesuje nas [...] oddziaływanie danej wypowiedzi, skutek, jaki wypowiedź ta może wywołać; [...] oddziaływanie [...] wiążące (użytkowników dyskursu), typowe, powszechnie stosowane" ${ }^{14}$.Na poziomie rozwiązań metodologicznych skupienie na skutku oznaczało rezygnację z uwzględniania i weryfikowania intencji autora wypowiedzi, a koncentrację na efekcie - komunikowanej ceszefelietonisty (tu: dociekliwość). Tę cechę wyłoniono w procedurze badawczej angażującej respondentów ${ }^{15}$, a na poziomie analizy uwzględniano dane ilościowe, by zidentyfikować elementy dyskursu typowe i zauważane przez większą liczbę interpretatorów.

${ }^{10}$ M. Fleischer, Konstrukcja rzeczywistości 2, Atut, Wrocław 2008.

${ }^{11}$ Tamże, s. 60.

${ }^{12}$ M. Fleischer, dz. cyt., s. 60; por. A. Awdiejew, G. Habrajska, Obrazyideacyjne w interpretacji tekstu, [w:] Rozmowy o komunikacji 5. Kategorialne aspekty komunikacji, red. G. Habrajska, Primum Verbum, Łódź 2011, s. 57.

${ }^{13}$ M. Fleischer, Typologia komunikacji, Primum Verbum, Łódź 2012, s. 29.

${ }^{14}$ M. Fleischer, Konstrukcja..., s. 99.

${ }^{15}$ Zob. tamże, s. 49-111. 


\section{Przebieg i warunki badania}

Całe badanie miało dość złożony charakter i jego głównym zadaniem było ustalenie, jaki wizerunek możliwy jest do komunikowania werbalnie, a także, jakimi metodami można wyrażać poszczególne cechy wizerunkowe, stąd też wyniki dotyczące cechy „dociekliwość” stanowią w istocie niewielką część uzyskanych rezultatów. Poniżej zatem omówione zostaną jedynie dwa z kilku wariantów badania -te, które są istotne w kontekście celu niniejszego tekstu.

Respondentom polecono wykonanie dwóch głównych, następujących bezpośrednio po sobie zadań. Pierwsze to przeczytanie felietonu (wydruk tekstu na kartce formatu A4) i odpowiedź na otwarte pytanie: „Mając za podstawę tekst przeczytanego felietonu, jakimi słowami opisałby Pan / opisałaby Pani autora tego tekstu?". Karta odpowiedzi miała pięć punktorów (kropek), po których respondentowi zostawiono puste miejsce na wpisanie cech felietonisty. Proponowano tym samym podanie pięciu przymiotów autora, chociaż żadnej cechy nie sugerowano. Drugie z poleceń brzmiało:,Proszę do każdej wskazanej przez Pana/Panią cechy autora felietonu wypisać z tekstu słowa/zdania/fragmenty, które stały się podstawą do wyłonienia danej cechy". Pierwsze pytanie (dotyczące określeń autora) pozwalało wyłonić konkretne cechy felietonisty, analiza odpowiedzi na drugie z kolei umożliwiała określenie sposobów komunikowania wskazanych cech.

W pierwszym wariancie badania autor tekstu pozostawał dla ankietowanych anonimowy. W drugim wariancie tożsamość felietonisty została ujawniona - uczestnicy otrzymali kserokopię strony z tygodnika, gdzie znajdowała się informacja o imieniu i nazwisku felietonisty oraz jego zdjęcie, w poleceniach także widniały konkretne wskazówki.

W całym badaniu wykorzystano teksty czterech felietonistów: Krzysztofa Vargi (publicysty „Dużego Formatu”- dodatku do „Gazety Wyborczej”), Piotra Zaremby (piszącego do,wSieci”, a wcześniej do tygodnika „Sieci” i „Uważam Rze”), Magdaleny Środy (felietonistki „Wprost”) oraz Szymona Hołowni (autora tekstów dla „Rzeczpospolitej”, wcześniej dla „Wprost” i „Newsweeka Polska”). Prezentowane wyniki związane z komunikowaniem dociekliwości dotyczyć będą Zaremby, Środy i Hołowni. Do badania wybrano felietonistów wypowiadających się w różnych kwestiach współczesnego życia (problematyka kulturalna i społeczno-polityczna) orazreprezentujących zdecydowanie odmienne postawy światopoglądowe. Ta dywersyfikacja problemowo-ideowa służyła uniknięciu determinacji wyników przez tematczy postawę autorów.

Wykorzystano gatunek felietonu, ponieważ ten rodzaj publicystyki daje największe możliwości ekspresji własnej osobowości, cechuje się bardzo dużą swobodą tematyczną i stylistyczną, a przy tym narzuca jednak pewne reguły i stanowi publikację cykliczną (co pozwala badaczowiposłużyć się kilkoma tekstami 
jednego autora). Dzięki jednorodności gatunkowej możliwe stało się porównywanie wyników dla poszczególnych twórców ${ }^{16}$.

Wśród respondentów znaleźli się studenci I oraz II roku dziennikarstwa i polonistyki kilku polskich uczelni: Uniwersytetu Łódzkiego, Uniwersytetu Wrocławskiego, Uniwersytetu w Białymstoku, Uniwersytetu im. Kazimierza Wielkiego w Bydgoszczy, Uniwersytetu Warszawskiego, Uniwersytetu im. Adama Mickiewicza w Poznaniu. Poproszono o dobrowolny udział słuchaczy tylko tych dwóch kierunków, założywszy ich optymalne kompetencje językowe i poziom elokwencji potrzebny w badaniu. Nie angażowano wyższych roczników ze względu na przewidywane zbyt duże kompetencje i świadomość języka, komunikacji oraz gatunków dziennikarskich. Wybór do badania studentów pokrewnych kierunków humanistycznych dwóch tylko roczników zapewnił też homogeniczność próby. Nie ograniczano czasu przeznaczonego na wykonanie zadań, nie przekraczał on jednak 15-20 minut. Ankiety tych, którzy na wykonanie polecenia poświęcili więcej niż 20 minut, pominięto w procesie analizy wyników.

Badanie przeprowadzono w trzech turach czasowych jednocześnie dla czterech felietonistów: wiosną 2012 roku, wiosną 2013 roku i jesienią 2013 roku. We wszystkich fazach taka sama liczba respondentów czytała przypadającą na każdego autora jednakową liczbę felietonów w tej samej liczbie wariantów całego badania i w identycznym układzie poleceń. Zastosowanie zasady proporcjonalności w procedurze badawczej umożliwiło porównywanie wyników.

W każdej turze czasowej wykorzystano siedem ostatnio publikowanych tekstów każdego z autorów, by zapewnić względną aktualność poruszanych w tekstach tematów (założono, że problem sprzed maksymalnie siedmiu tygodni wciąż będzie łatwy do wywołania z pamięci czytelnika) ${ }^{17}$.

${ }^{16}$ Definicja felietonu uwzględniająca najważniejsze jego aspekty: „Felieton jest stałą pozycją w dziennikach, tygodnikach, miesięcznikach, także w mediach elektronicznych. Zajmuje się najczęściej aktualnymi w danym momencie wydarzeniami kulturalnymi, społecznymi, gospodarczymi. Powinien być pisany dla rozrywki czytelników, w tonie swobodnym o dużym zabarwieniu satyrycznym, nawet skandalizującym. Swoboda językowafelietonu wiąże się z wolnością tematyczną. Autor felietonu ma prawo manifestować swój subiektywny punkt widzenia, podkreślać uczuciowość i zaangażowanie w dane sprawy. Wypowiedź jego cechuje familiarność i podkreślanie wolności intelektualnej. Stylistycznie felieton korzysta z mowy potocznej (w tym kolokwializmów, nawet wulgaryzmów), ale i ze środków typowo literackich, a także prawa do kreowania fikcji” (K. Wolny-Zmorzyński, A. Kaliszewski, Gatunki publicystyczne, [w:] K. Wolny-Zmorzyński, A. Kaliszewski, W. Furman, Gatunki dziennikarskie. Teoria, praktyka, język, Wydawnictwa Akademickie i Profesjonalne, Warszawa 2006, s. 88); zob. też jedno z obszerniejszych i chyba najbardziej wyczerpujących opracowań dotyczących tego gatunku [w:] M. Wojtak, Felieton - informacja zakamuflowana, [w:] tejże, Gatunki prasowe, Wydawnictwo UMCS, Lublin 2004, s. 202-237.

${ }^{17}$ Jeśli posłużono się tekstami publikowanymi w dłuższej perspektywie czasowej, wynikało to najczęściej z zakłócenia rytmu publikacji przez samego autora, tj. jego felieton nie ukazywał np. w dwóch kolejnych wydaniach tygodnika. W takich sytuacjach, choć niemożliwe było 


\section{Wyniki}

Przedstawiane niżej wstępne wyniki dotyczą 378 ankiet wypełnionych przez 378 respondentów, z czego połowa przypada na wariant, w którym uczestnicy czytali tekst anonimowego autora, a połowa na wariant, gdzie jego tożsamość została podana. W każdym wariancie, w każdej z trzech tur czasowych, 7 różnych felietonów każdego z trzech autorów (Piotr Zaremba, Magdalena Środa, Szymon Hołownia) było czytanych przez trzech respondentów (2 warianty badania x 3 tury czasowe x 7 ostatnich felietonów x 3 autorów x 3 czytania $=378$ ankiet). Uczestnicy badania przypisywali wszystkim autorom tak różne cechy, jak np.: „,inteligentny”, „krytyczny”, „,konserwatywny”, „lewicowy”, „,dowcipny”, ,antyklerykał”, „podróżnik”, „szczery”itd. Wśród określeń nadanych Zarembie, Środzie i Hołowni pojawiało się także „dociekliwy”. Wstępne obliczenia wykazują, iż łącznie tę cechę przypisano 55 razy.

Tabela 1. Liczba wskazań cechy „dociekliwość”

\begin{tabular}{|l|c|}
\hline wariant: znana tożsamość autora & dociekliwy \\
\hline Zaremba Piotr & 9 \\
\hline Środa Magdalena & 10 \\
\hline Hołownia Szymon & $\mathbf{2 3}$ \\
\hline razem dla wariantu & \\
\hline wariant: anonim & 12 \\
\hline Zaremba Piotr & 10 \\
\hline Środa Magdalena & 10 \\
\hline Hołownia Szymon & $\mathbf{3 2}$ \\
\hline razem dla wariantu & $\mathbf{5 5}$ \\
\hline lącznie &
\end{tabular}

Źródło: oprac. własne.

Jak ilustruje tabela 1, epitet „dociekliwy” przypisuje się w bardzo podobnych proporcjach, bez względu na fakt, czy felietonista był anonimowy czy znany uczestnikom badania. Jednocześnie popularny autor jest dużo rzadziej (23 razy) wskazywany jako „dociekliwy” niż ten, którego tożsamość pozostaje nieznana (32 wskazań). Istotna różnica dotyczy jednak wyłącznie jednego felietonisty. W obu grupach czytano te same teksty, zatem znaczenie może mieć wysoka roz-

wykorzystanie wypowiedzi z ostatnich siedmiu tygodni, wciąż obowiązywała zasada wykorzystania siedmiu ostatnio opublikowanych felietonów. 
poznawalność Hołowni, która prawdopodobnie spowodowała, że wizerunek pozafelietonowy - gdzie ,dociekliwość” nie dominuje - miał wpływ na odczytanie jego tekstów ${ }^{18}$ i nie tak częste przypisywanie tej cechy. Jak pokażeanaliza, na poziomie werbalnym wartość komunikacyjną mają elementy dyskursowe i to one przede wszystkim wpływają na sposoby wyrażania danej cechy.

W nawiasach następujących po cytowanych niżej przykładach podano inicjały autora słów (PZ - Piotr Zaremba, MŚ - Magdalena Środa, SH - Szymon Hołownia), skrót od nazwy periodyku, w którym opublikowany został tekst, z jakiego zaczerpnięto cytat ( $\mathrm{S}$ - „Sieci”, WS - „W Sieci”, UR - „Uważam Rze”, W - „Wprost”, N - „Newsweek”, R - „Rzeczpospolita”), a także numer tygodnika (po ukośniku rok wydania) lub datę publikacji danego egzemplarza dziennika. W nawiasach kwadratowych znajdują się fragmenty, których niewypisano na karcie ankietowej, ale ich niezbędność zaznaczył respondent za pomocą wielokropka lub też autorka badania uznała podanie konkretnych słów za istotne komunikacyjnie. Nie zauważono różnic w samych sposobach komunikowania omawianych tu cech w zależności od wariantu badania (anonimowy/znany autor), dlatego poniżej nie podaje się tej informacji.

\section{Komunikowanie cechy „dociekliwość”}

Uczestnicy badania uznali 55 razy felietonistę za „dociekliwego”, przy czym raz nie podano żadnego cytatu, pięciokrotnie zaś podane fragmenty nie dały się ani dopasować do żadnej z wyłonionych metod komunikowania omawianej cechy, ani nie stanowiły odrębnego sposobu, dlatego też sklasyfikowane zostały jako „inne”. W analizie uwzględniono tym samym 54 określenia „dociekliwy”, do których wypisano słowa/zdania czy fragmenty z felietonu odpowiadające za komunikowanie tej cechy.

Analiza przytoczonych przez respondentów cytatów, które ich zdaniem są wyrazem dociekliwości autora wypowiedzi, pozwala wyłonić takie sposoby komunikowania tej własności, jak: stawianie pytań, deklaracja zaciekawienia, deklaracja szukania informacji, sformułowanie spostrzeżenia/wniosku/podsumowania - diagnozy, rozpatrywanie zjawiska z uwzględnieniem jego wieloaspektowości, zwracanie uwagi na szczegóły.

Najczęściej, bo aż 19 razy, dla respondentów zastosowanie pytania było przejawem dociekliwości. Taki sposób komunikowania tej cechy może zaskakiwać, jeśli zauważymy, że wskazywane pytania reprezentują pytania retoryczne,

18 Por. A. Barańska-Szmitko, Wizerunek Szymona Hołowni komunikowany w jego felietonach, [w:] Badanie i projektowanie komunikacji 3, red. M. Wszołek, Libron, Wrocław 2014, s. 173-197. 
zadane nie w celu uzyskania odpowiedzi, lecz dla przykucia uwagi, zaangażowania słuchaczy, wywołania procesu myślowo-emocjonalnego, wywarcia pożądanego przez mówcę wpływu na słuchaczy ${ }^{19}$. Z założenia więc pytanie retoryczne jest działaniem mającym wpłynąć na odbiorcę i ma związek z tematem, tj. służy głównie zwróceniu uwagi i przekonaniu do pewnych poglądów czy postawy. Tymczasem uczestnicy badania uznają ten zabieg stylistyczny/retoryczny za wyraz cechy autora wypowiedzi.

Pytaniami posługiwano się nimi na różne sposoby. Np. wykorzystywano ich nagromadzenie, by wzbudzić wątpliwości w odbiorcy:

A kto zapłaci dzielnej blogerce za dziennikarskie śledztwo? Kto ją będzie uczył zawodu, zapewniał dostęp do ważnych miejsc i ludzi? I czy gdyby dziennikarz odcięty od gazet wrzucił swoje rewelacje do Internetu, wygrałby wojnę z potężnymi? Czy nie zginąłby w kakofonii tysięcy głosów? (PZ, UR, 19/2012)

Kto rozumie język ,postępowców”? Kto rozumie „Krytykę Polityczną”? Kto w ogóle pojmuje, co się dzieje na lewicy? Czymże jest dziś postęp, którego wyrzeka się nawet Donald Tusk? Trzeba o tym czytać, dyskutować, studiować...(MŚ, W, 13/2013)

Stanowczy kardynał Ouellet? Błyskotliwy Scola? Genialny Ravasi? Rubaszny (i mądry) Dolan? Pistoletowy Pell? Emocjonalny Tagle? Pracoholik Scherer? (SH, W, 10/2013)

Wskazywano także pojedyncze zdania, umieszczane najczęściej pod koniec akapitu niejako w roli podsumowania myśli i prowokowania do zastanowienia:

Nie wiem tylko, czy robi tak świadomie, z ignorancji, czy ze strachu? (MŚ, W, 16/2012)

Aktorka thumaczy, że zmieniła ten sens swoją grą. Ale czy zmieniła ideowe przesłanie całego teatru Warlikowskiego? (PZ, WS, 38/2013)

Na powyższe pytania autorzy nie dają odpowiedzi. Ale wskazywano również takie fragmenty, w których bezpośrednio po pytaniu pojawiała się zwięzła odpowiedź (respondenci nie cytowali na karcie ankietowej odpowiedzi):

Truskolaski cofnął patronat honorowy dla odbywającej się w Białymstoku wielkiej konferencji Kongresu Kobiet zorganizowanej przez przedsiębiorczynie. Dlaczego? (MŚ, W, 41/2013)

${ }^{19}$ K. Szymanek, Sztuka argumentacji. Stownik terminologiczny, Wydawnictwo Naukowe PWN, Warszawa 2005, s. 264. 
Ale liczby te maleją, bo w 1997 r. masturbowało się 55 proc. mężczyzn i 37 proc. kobiet. O czym to świadczy? (MŚ, W, 15/2012)

O dociekliwości felietonisty świadczy też postawienie jednego pytania, na które odpowiedzią był cały lub prawie cały felieton. Wyrazistym przykładem jest pytanie zawarte w tytule: „co można zrobić za 2,6 mln?” (MŚ, W, 20/2012). Uczestnicy badania podalirównież takie początkowe fragmenty z wypowiedzi Piotra Zaremby:

Ta inscenizacja, zrobiona w sumie po bożemu (choć z paroma tajemniczymi sygnałami od Jarockiego, ale Mrożka chyba udziwnić się na dobre nie da), każe zapytać: czemu zachwyca? I czy zachwyca? (PZ, WS, 34/2013)

Zawsze pojawia się pytanie podstawowe: czy pokazano nam coś, co przetrwało próbę czasu. (PZ, S, 18/2013)

Za przejaw dociekliwości uznano też fragment, zdaje się, czysto humorystyczny:

Pomału rośnie liczba osób, które uprawiają seks „,na łonie natury” (38 proc.), „w samochodzie” (40 proc.), „w metrze” (4,3 proc.) oraz „w windzie”. To ostatnie miejsce wybiera 1,3 proc. kobiet i aż 3 proc. mężczyzn. Trudno powiedzieć, czy wybór taki bierze się z braku własnego mieszkania czy z fantazji. W przypadku windy należy jednak zapytać, co w niej robi 1,7 proc. mężczyzn bez kobiet? (MŚ, W, 15/2012)

Jak więc widać, bardzo różne typy pytań o niejednorodnej strukturze i funkcji tekstowej stały się przejawem ,dociekliwości”. Nie tylko jednak zadawanie pytań, ale także sama deklaracja zaciekawienia lub szukania informacji są wystarczające, by zostało mówiącemu przypisane omawiane określenie.

Czytelnicy zauważali deklarację zaciekawienia, realizującą się przede wszystkim poprzez pojawienie się formuły ,ciekawi mnie”:

nieco ciekawi mnie (...) (MŚ, W, 20/2013)

W tym kontekście niezwykle ciekawi mnie (...) (MŚ, W, 20/2013)

Kardynał Maradiagaciekawił mnie od dawna (...) (SH, R, 12-13.10.2013)

Często (aż trzykrotnie) badani wskazali identyczny fragment:

Chciałbym, aby ktoś mnie w końcu oświecił w kwestii elektrowni atomowych.(PZ, UR, 13/2012) 
Ośmiokrotnie wypisywano słowa, w których autorzy deklarowali szukanie informacji:

Szukałam dowodów, rozmawiałam z jego [Jana Marii Rokity] wielbicielami, z nim samym, czytałam jego teksty. (MŚ, W, 18/2012)

[Mimo wszystko „DowntonAbbey” pokazywany w TVP1 w poniedziałkowe wieczory to fenomen. Przemysłowa produkcja, która tak świetnie udaje rękodzieło], że szukałem pisarza, którego w ten sposób zaadaptowano. (PZ, S, 21/2013)

Wyszperałem ten film (...) (PZ, UR, 19/2012)

„Spartakus” (zerknąłem na kilka odcinków) (...) (PZ, UR, 15/2012)

Siedmiokrotnie wynotowano fragmenty stanowiące rodzaj spostrzeżenia/ wniosku czy podsumowania danego zjawiska, diagnozy omawianej sytuacji:

Podejrzewam, że atak na gender może być oryginalną próbą odwrócenia uwagi od problemów związanych z pedofilią wśród kleru. (MŚ, W, 41/2013)

[kardynałowie] są niejako winni ponad miliardowi katolików swoją diagnozę instytucji Kościoła. (SH, W, 11/2013)

Naturalne kiedyś byli bardziej rzewni i patetyczni, potem wkradła się nutka rewizjonistycznego sarkazmu. (PZ, WS, 37/2013)

Logika: skoro coś sobie myślę, a znam dogmaty, to w takim razie to, co sobie myślę, to też dogmat. Ile trzeba pychy, by papieskie wypowiedzi traktować jak zimny bufet, z którego możemy sobie wybrać to, co nam pasuje (SH, N, 20/2012)

Oprócz swego rodzaju oceny zjawiska, przejawem dociekliwości jest także zwrócenie uwagi na jego wieloaspektowość. Pięć osób podało np. takie fragmenty:

Wkońcu poglądy, nawet radykalnie prawicowe, mogą być czymś więcej niż wolną ekspresją tego, co ślina na język przyniesie, a czego poczucie wstydu nie zahamuje. Poglądy (każde) można budować na argumentach, posiłkując się wiedzą, budując związki wynikania między racjami. Można kształcić talenty krasomówcze, troszczyć się o język, pamiętając, że parlament jest szkołą wolności dla wszystkich. A jakiej wolności można się nauczyć od najbardziej krzykliwych parlamentarzystów? Jakiejś strasznej wolności. (MŚ, W, 40/2013) 
Feministki zasiadły na barykadzie i nie wiedzą, jak z niej zejść - z jednej strony oskarżają Zumę o „maskulinistyczny konserwatyzm”, podkreślają, że poligamia to historia strasznie seksistowska, kolejna kobieta jest tu bowiem traktowana jak następny samochód, emblemat sukcesu mężczyzny (twoją zdolność kredytową określa to, ile żon jesteś w stanie wykarmić i ubrać). Z drugiej - kobiety Zumy to nie są jakieś gąski, a jeśli wykształcona, robiąca karierę kobieta chce zrealizować swoje prawo do bycia szczęśliwą nawet w niestandardowym związku, to przecież jest to coś, o co wszystkie postępowe ruchy walczą na całym świecie. (SH, N, 19/2012)

respondent: Rozstrzyga temat na kilka sposobów²0: idealizują Dziki Zachód; wobec Indian; liberalna w stosunku do kwestii rasowych; idealizowała rodzinę; Serial uczył traktować je [kobiety] podmiotowo (PZ, WS, 33/2013)

Zwracano również uwagę na szczegóły jako sposób komunikowania dociekliwości. Wynotowano słowa wyłącznie z felietonu Środy, referującego wyniki badań z książki Zbigniewa Izdebskiego Seksualność Polaków na początku XXI wieku ${ }^{21}$ :

67 proc. Polaków i Polek jest bardzo zadowolonych z seksu; „w samochodzie” (40 proc.), ,W metrze” (4,3 proc.) (MŚ, W, 15/2012)

dostęp do informacji: Gdzie się kochamy? Głównie - w domu (97 proc.). Pomału rośnie liczba osób, które uprawiają seks „,na łonie natury” (38 proc.), „w samochodzie” (40 proc.), „w metrze” (4,3 proc.) oraz ,w windzie”. To ostatnie miejsce wybiera 1,3 proc. kobiet i aż 3 proc. mężczyzn. (MŚ, W, 15/2012)

Podawanie szczegółów zdaje się być jednak mało ,produktywnym” sposobem wyrażania omawianej cechy. Wskazały ją bowiem tylko dwie osoby.

\section{Podsumowanie i wnioski}

Jak zatem pokazują wyniki analizy, można komunikować dociekliwość na kilka różnych sposobów. Da się wyróżnić sześć form wyrażania tej cechy wizerunku (zob. Tab.2), z których najczęstszą i tym samym najbardziej wyrazistą, stanowiącą $35 \%$ wszystkich wyłonionych, jest zadawanie pojedynczych lub nagromadzonych pytań. Dużo mniej reprezentowane, ale wciąż w dużym stopniu manifestowane

\footnotetext{
${ }^{20}$ Kursywą wypowiedź respondenta. Następnie cytat z felietonu P. Zaremby, przytoczony przez uczestnika badania.

${ }^{21}$ Z. Izdebski, Seksualność Polaków na początku XXI wieku, Wydawnictwo Uniwersytetu Jagiellońskiego, Kraków 2012.
} 
w przytoczeniach (po 15\% wskazań) są: deklaracje zaciekawienia i deklaracje szukania informacji. W nieco mniejszym stopniu (niespełna 13\%) formułowanie spostrzeżeń/wniosków/podsumowań - diagnoz może zostać uznane za przejaw dociekliwości. W nieco ponad 9\% wypisanych przez badanych fragmentach zwracano uwagę na wskazywanie na wieloaspektowość zjawiska jako wyraz omawianej cechy, a tylko 3,7\% wypisanych cytatów dotyczyło podawania szczegółów.

Tabela 2. Sposoby komunikowania cechy „dociekliwość”

\begin{tabular}{|l|c|c|}
\hline sposób komunikowania dociekliwości & n & \% \\
\hline pytania & 19 & 35,19 \\
\hline deklaracja zaciekawienia & 8 & 14,81 \\
\hline deklaracja szukania informacji & 8 & 14,81 \\
\hline diagnoza & 7 & 12,96 \\
\hline wieloaspektowość zjawiska & 5 & 9,26 \\
\hline szczegóły & 2 & 3,70 \\
\hline inne & 5 & 9,26 \\
\hline razem & 54 & 100,00 \\
\hline
\end{tabular}

Źródło: oprac. własne.

Zdecydowanie największą efektywnością w omawianym zakresie oznaczają się pytania. Istotne wydaje się, że stawiane $\mathrm{w}$ tekstach pytania mają charakter czysto retoryczny, ukierunkowany na zainteresowanie i przekonanie odbiorcy do określonych poglądów. Badanie ujawniło jednak ich dużą zdolność do komunikowania dociekliwości autora wypowiedzi. Efekt komunikacyjny dotyczy więc także nadawcy komunikatu. Okazuje się tym samym, że pytania mogą pełnić funkcję specyficznego kamuflażu wpływu. Czytelnik zauważa cechę felietonisty, nie zauważając aspektu perswazyjnego (wśród przypisywanych dziennikarzom cech nie pojawiały się takie, które sugerowałyby, że czytelnicy są świadomi wywieranego na nich wpływu).

Dociekliwość zdaje się być cechą uniwersalną, tj. jej komunikowanie nie zależy ani od poruszanego tematu (kultura, kwestie społeczno-polityczne), ani od płci wypowiadającego się.

Oprócz przypadku Hołowni, nie zauważono różnic w wynikachmiędzy grupą znającą tożsamość felietonisty a grupą czytającą anonimowy tekst. W obu wariantach badania respondenci i Zarembie, i Środzie tak samo często przypisywali omawianą cechę. Znaczenie więc może mieć wiedza o wypowiadającym się, a w szczególności wizerunek pozafelietonowy autora, jeśli słabo jest związany z „dociekliwością”. Uwzględnienie wyników dotyczących Vargi pozwoli poszerzyć analizę o nowe dane i pogłębić wnioski. 


\section{Bibliografia}

Fleischer M., Konstrukcja rzeczywistości 2, Atut, Wrocław 2008.

Fleischer M., Typologia komunikacji, Primum Verbum, Łódź 2012.

Hołownia Sz., Kardynat na froncie, „Rzeczpospolita” 2013, nr 239, s. 2.

Hołownia Sz., Ojciec Rydzyk jest naszym lustrem, „Newsweek Polska” 2012, nr 20, s. 31.

Hołownia Sz., Przed konklawe, „Wprost” 2013, nr 10, s. 57.

Hołownia Sz., To nie piekarnia, „Wprost” 2013, nr 11, s. 69.

Hołownia Sz., Wartość tradycji, „Newsweek Polska” 2012, nr 19, s. 38.

Szymanek K., Sztuka argumentacji. Stownik terminologiczny, Wydawnictwo Naukowe PWN, Warszawa 2005.

Środa M., Kukiz zbliża się, „Wprost” 2013, nr 13, s. 52.

Środa M., Polityk inteligentny inaczej, „Wprost” 2012, nr 18, s. 40.

Środa M., Polski seks typu A, „Wprost” 2012, nr 15, s. 44.

Środa M., PO-PiS wiecznie żywy, „Wprost” 2012, nr 16, s. 32.

Środa M., Straszna wolność, „Wprost” 2013, nr 40, s. 6.

Środa M., Świat na opak wywrócony, „Wprost” 2013, nr 20, s. 42.

Środa M., Widmo krąży po Europie i... Białymstoku, „Wprost” 2013, nr 41, s. 38.

Wolny-Zmorzyński K., Kaliszewski A., Gatunki publicystyczne, [w:] K. Wolny-Zmorzyński, A. Kaliszewski, W. Furman, Gatunki dziennikarskie. Teoria, praktyka, język, Wydawnictwa Profesjonalne i Akademickie, Warszawa 2006, s. 85-109.

Zaremba P., Angielskie pogwarki, „Sieci” 2013, nr 21, s. 51.

Zaremba P., „Bonanza”- utracone dzieciństwo, „wSieci” 2013, nr 33, s. 71.

Zaremba P., Dwie aktorki: studium zagubienia, „wSieci” 2013, nr 38, s. 58.

Zaremba P., Elektrownie w kisielu, „Uważam Rze” 2012, nr 13, s.45.

Zaremba P., Hrabia Fredro krzepi, „Sieci” 2013, nr 18, s. 51.

Zaremba P., Jak John Adams zostat Amerykaninem, „wSieci” 2013, nr 37, s. 58.

Zaremba P., Kim była siostra Henryka VIII, „Uważam Rze” 2012, nr 15, s. 55.

Zaremba P., Ostatnie zwycięstwo mediów nad złem, „Uważam Rze” 2012, nr 19, s. 45.

Zaremba P., „Tango” Mrożka dzieje się dziś,,wSieci” 2013, nr 34, s. 73.

Anna Barańska-Szmitko

The verbal means of communicating of "inquisitiveness" by the columnist:

Piotr Zaremba, Magdalena Środa and Szymon Hołownia

Results of empirical research

(Summary)

The main research problem presented in this paper is the communication of one of many features of personal image - the trait 'inquisitive'. The paper presents the results of the research which used quantitative methods and discourse analysis in order to examine what image can be created when somebody is talking/writing about various subjects but not about him/herself. The results 
of the research shows that it is possible to indicate six ways of communicating "inquisitiveness": questions, declaration of interest, declaration of information searching, insight/conclusion, multifaceted issue, details.

Keywords: column, columnist, image, image research, discourse analysis, style. 